\title{
Low cost construction: State of the art and prospects for using structure wood apartment buildings in Portugal
}

\author{
M. Oliveira, J. P. Couto, P. Mendonça, J. Branco, M. Silva \& A. P. Reis \\ University of Minho, Guimarães, Portugal
}

\begin{abstract}
The Low cost concept in buildings is normally associated with the construction of social housing. Today, with the economic crisis, this concept becomes increasingly important to all areas and in the different social hierarchies. Low cost architecture emerges as the demand to find economical constructive solutions, but still allowing good visual, hygrothermal and acoustic performances. Wood emerges as an excellent material able to achieve all these objectives. The ease decomposition and re-composition of prefabrication wood systems allow the flexibility of the building components, being capable of generating multiple combinatorial possibilities, customized and capable of responding to the users' changing requests.

This work aims to make a description of the evolution of the low cost concept within the industry of building construction, to provide a description of the state of the art and characterization of the potential of wood structures in multi-storey buildings, and place this type of structural solution in the "purposes" or objectives of the low cost construction.
\end{abstract}

\section{INTRODUCTION}

\subsection{Construction market}

With the increased difficulties in the construction sector, "new architectural" concepts rise, coupled with low cost concerns, and taking into account principles such as safety and comfort of users that occupy the buildings or public space, ensuring the welfare and comfort of the users.

Nowadays, when someone decides to go on with the construction of its own house, it faces the question whether to use the traditional construction with an initial low cost but no future possible adaptability or an alternative construction that guarantees a better cost/benefit ratio in the long term, admitting future changes in the use.

In Portugal, there has been some recent investment in the low cost building systems. The low cost term was usually associated with the construction of social housing. However, nowadays with the economic crisis, it becomes increasingly important to apply this concept to all areas and in different social strata. In making use of materials and techniques with a better cost/benefit ratio in the long term, a new attitude to the building design, is giving way to informal composition with simple modular shapes, but that still allows the correct relationship with the surrounding public space.

Following this logic, modular homes represent a niche market in the construction industry that has grown from year to year, especially because it is considered a fairly cheap option.

Across Europe, since the beginning of the $21^{\text {st }}$ century it is notorious the implementation of modular housing solutions. One such example is the Keetwonen (Figure 1), Amsterdam. It is the largest modular container city in the world, built for temporary residences with over 1000 units in high strength steel prefabricated modules. These can be combined to create a wide variety of typological forms that adapt to the needs of the user and the terrain. Outside Europe we can find 
in Australia the accommodation of the Australian National University, in Camberra (Figure 2). Each module you see in the photos is essentially like a prefabricated shipping container.

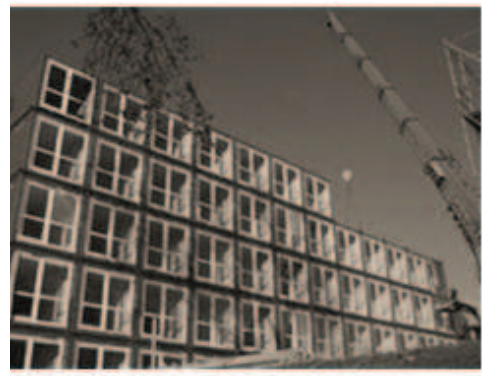

Figure 1. Left: City of modular steel containers, Keetwonen

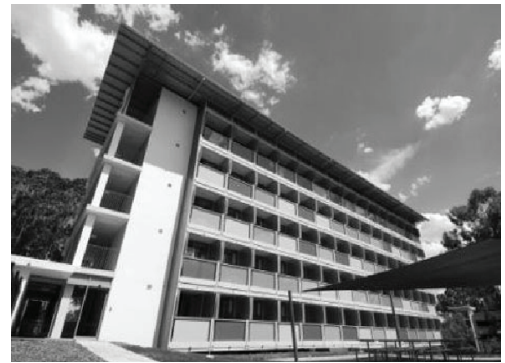

Figure 2. Australian National University's accommodation, Camberra (Obtained in the web site of "Architecture and Design": http://www.architectureanddesign.com.au)

The modular architecture is based on an element that is repeated and customized as needed by customer requirement, always in a type which can be adjusted according to the needs. The advantages of applying modularity in housing are the reduced time of construction - tenants can be themselves involved in the construction - and consequently cost reduction. It also allows a more rigorous and quicker control of costs in the preliminary design phase; eliminating the difficulties/problems in transposing the rigor and concerns of the project on "paper" for the built work and providing simplification and compatibility of designs.

The modular houses are typically buildings that rely on materials and prefabricated components, acquiring different uses, temporary or permanent. Applying the material being developed with modular forms such as wood and its derivates, it becomes easier to apply the theoretical concept into practice in carrying out the work.

The modular architecture defines itself as a "sustainable process," that is, if the location of the building is changed, its materials can be reused. It also allows an ease adaptation to changing lifestyles, which are nowadays increasingly mutable. The modulation allows increasing or eliminating the living spaces in an evolutionary system, maintaining the proportion and size of shapes and allowing flexibility of space use, adding and removing modules without affecting the rest of the system.

The concept of modularity abandons the idea of conventional housing fostering the creation of spaces based on a set of modules. It is a model for industrialization, which is further turned to the construction process rather than for the final product.

Wood construction can be developed as a modular construction system. Given the advantages inherent of using wood, it is accepted that this is a building system that best suits the issues previously cited - modular architecture, low cost construction, the possibility of prefabrication and environmental consciousness.

Regarding to construction market in Portugal, despite the developed investigations in the wood construction, there has been a stagnation of the construction of multifamily wood frame buildings, being more common the construction of single family houses.

\subsection{Wood building construction - an overview}

Since ancient times that wood is contributing as raw material for the humanity. The reason for this prominence is the number of properties and characteristics of wood: it is a "user friendly" material; ease handling and processing; it is generated with low energy; high strength; great thermal insulation; it is available in a variety of colors and textures; and finally it is fully recyclable.

During decades, the construction of wooden houses encircled only the single family dwellings. It was the demand for apartment buildings, which varies among countries, that in generally influences, in inverse proportion, the demand for wood construction. The number of households is more decisive in terms of housing demand than population size. In Europe, families comprised of fewer elements, but the number of households tends to increase (expected to be $20 \%$ 
higher in 2030 than in 2005) promoting the growing demand for apartments, Mahapatra \& Gustavson (2009).

Along the nineteenth century, in most countries of Western Europe, it was forbidden to build multifamily dwellings in wood structure, due the high number of fires associated with this construction material, however, the concept was reintroduced in the early 1990s according to Espíndola\& Moraes (2010). In some European countries, the revision of regulations that limited the construction of multi storey wood buildings propitiated the construction of multifamily wood buildings with several floors. However, it is still rare to find in European countries huge buildings with wood structure. In Europe, Sweden stands out in the construction of multifamily wood housing in accordance with Pascoal, (2011). The reason for this lies, perhaps, in the long tradition of the use of wood in the building construction market, and also because the wide supply of this raw material in that country according Vessby (2008). In comparison, outside Europe, it is common to find multifamily wood buildings in the United States and Canada.

In Portugal, wood buildings are only single-family houses. So far, there is no record of multifamily housing in wood; in fact there is some resistance to the introduction of wooden construction. Factors such as the high humidity levels, the greater propensity for biological attack, the reduced supply of excellent raw material, the reduced mobility of the families, the shortage of skilled professionals, poor training given at national universities and the lack of regulation have contributed to this resistance according to Cruz, Morgado \& Pontífice (2012). Nevertheless, the necessity of finding solutions that address the reduction of environmental impacts in order to achieve the targets set by the European Union, has led to an increased interest for using wood as a building material.

Regarding the construction of multifamily buildings with multiple floors, there are differences between European countries, which limit the number of floors in wooden buildings. To visualize national legislation about number of storeys and to be able to compare the situation in different countries of the Europe is shown on the map below.

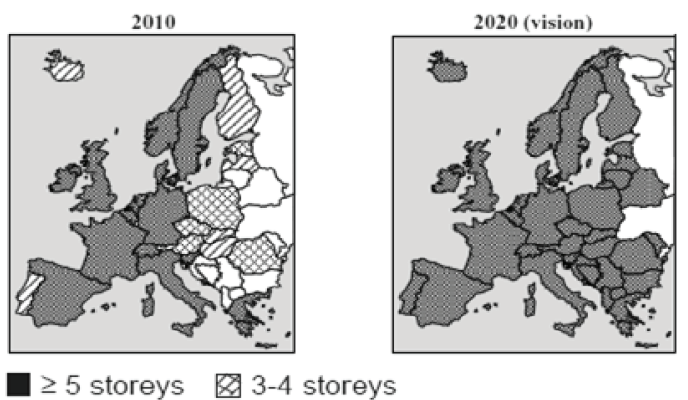

$\square \leq 2$ storeys (incl 0 ) $\square$ No information

Figure 3. Maximum number of storeys in timber - load-bearing structure without sprinklers (http://www.google.pt/url?sa =t\&rct=j\&q=\&esrc $=$ s\&source=web\&cd=1\&ved $=0$ CCEQFjAA\&url=http $\% 3$ A\%2F\%2Fwww.tresenter.no\%2FTechnical Guideline Summary SP Info 2010-

15_ENG_NEZqz.pdf.file\&ei=re9NUPW5KMOXhQeIy4GYCQ\&usg=AFQjCNFCgEAq_DfKPcyoi4Xr Wč $6 \mathrm{pWP}$ WeWw)

As we can see in Figure 3, in 2010, big differences between European countries have been identified. However, several countries have no specific regulations, or do not limit the number of storeys in wood buildings. It is predicted that in 2020 the great majority of European countries will allow multi storey wood frame construction with over five storeys.

\section{STRUCTURAL CONSIDERATIONS OF WOOD CONSTRUCTION}

\subsection{Construction systems}

Multi-residential timber frame construction is providing to be cheaper and faster to build than equivalent buildings in concrete or steel. Wood is a timeless building material and it has been desired for its structural capabilities. When properly designed and used, wood has very few structural limitations. 
Multi-family units can be built using the same techniques applied in the construction of single family modules and must followed the same European standards. Wood-based products like solid-sawn lumber for studs, rafters and beams/headers, wood I-joists, LVL and glulam for beams, structural panels, are normally used for wood frame construction projects. In terms of technology, timber systems are prone to be prefabricated. The prefabrication may consist of two different forms: closed systems and open systems according to Staib, Dorrhofer, \& Rosenthal (2008)

Staib, Dorrhofer, \& Rosenthal (2008) says that in a closed system produced by a single manufacturer, there is the modular construction consisting on a unique system in which all components constituting a predefined space already attached without the possibility of change. The module is manufactured in factory, ready to be placed on the construction site. After, the modules may be combined in several ways to build a larger house in accordance with Blauvelt (2007). Most of the modules are placed in field already with painting and final cover. This type of construction is applied where time is the essential element, Staib, Dorrhofer, \& Rosenthal (2008)

In an open system there are two possibilities: panels systems and systems of post and beams. In the panels systems one can find the ballon frame system and the platform system which are the most widespread systems for the construction of timber buildings. The last one is more widely used. Panels of plywood or oriented strand boards (OSB) are fixed to the wood profiles (using steel nails, screws or special pins) generally spaced 400-600 mm (Figure 4). The walls, which are normally manufactured in factory, are joined together on site. In result, there is a better control over the wastes, costs and quality of materials, Kaufmann \& Remick (2009). Beyond the fast assembly, this technique has the advantage of lightness that is an interesting aspect for grounds with low capacity and also ensures easy transport and assembly. These systems offer the possibility of integrating several manufacturers, combining different prefabricated components, Staib, Dorrhofer, \& Rosenthal (2008). However, this system assumes that all elements are structural which restricts the modularity and versatility concept due to impossibility of removing structural elements.

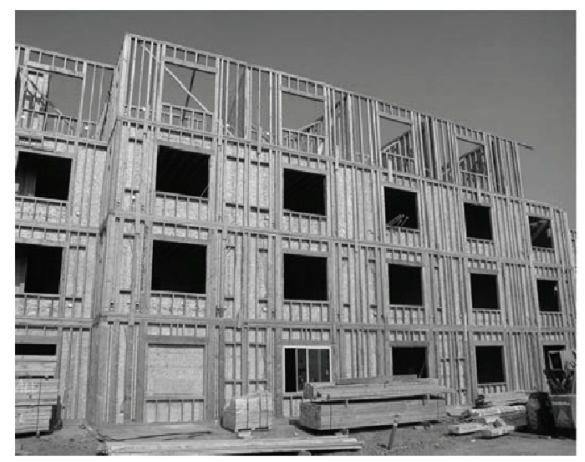

Figure 4. Platform system

In recent years, wood industry have proposed and developed glued laminated panels for the construction of floors and exterior or interior walls (Figure 5). Moreover, these panels can be used for bracing and ensures a load-carrying capacity difficult to achieve with others woodbased materials.

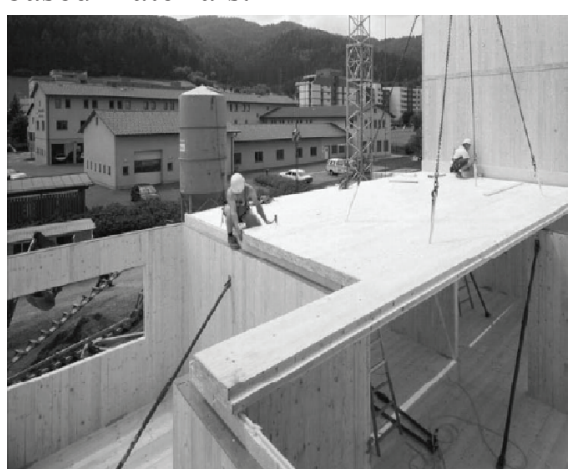

Figure 5. Structural glued laminated panels system

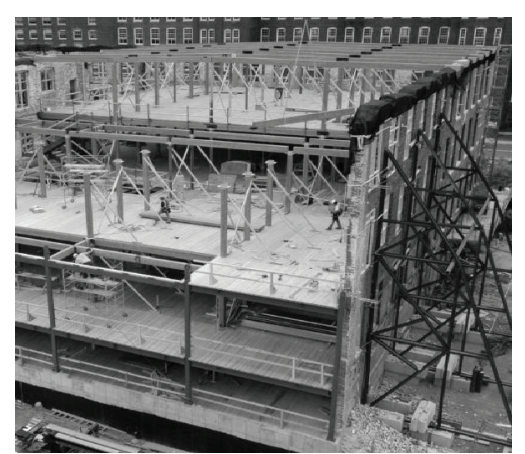

Figure 6. System of posts and beams 
In an open system there are two possibilities: systems of posts and beams and panels systems (Figure 6). In this system only the posts and the beams has structural role and the remaining elements that comprise the buildings (e.g. interior and exterior walls) are non-structural elements. The technical dissociation between the structure of posts and beams with the walls allow a large conception liberty: architecture of light (large glazed openings) and liberty of creation (possibility for removing or changing walls). However, the stability of the building considering the lateral and vertical actions and also the imperfections (misalignment of posts) depends on the stiffness of the beam-post connections. If the connections are flexible, the bracing frames could be made using, for example, shear walls. In this case the degrees of freedom are reduced due the larger number of structural elements.

\section{FUNCTIONAL AND ENVIRONMENTAL ASPECTS}

Wood construction systems are usually heavy. This factor affects the thermal inertia of the building, whose function is to counteract the interior temperature variations. Thus, a wood construction is usually classified as low inertia, which creates doubts in the people about the thermal performance of the building. The thermal insulation of the wood framing walls can be done by the outside (ETICS), in the middle air gap as it happens in traditional brick walls, or by the inside, but always with less thickness and with no need for concerns with thermal bridges. This means that all the parts of the wood wall, including the structural parts are accounted in the calculation of the thermal insulation.

Walls made according to the platform system are executed with OSB, wood profiles, insulation and plasterboard which are low-mass elements (Figure 7). According with the definition of thermal inertia, the walls have less ability to retain heat. Nevertheless, wood provides thermal comfort because it presents an high Heat Capacity. It is an excellent insulating structural material, being considered the best when compared with metals and concrete. Additionally, the wood construction is characterized by the absence of thermal bridges reducing the heating and cooling needs. The wood floors can also be executed in a similar way to the walls. These are constituted essentially of floor joists (massive section, I-joists), wood particle boards (OSB, wood cement board), thermo-acoustic insulation and plasterboard (Figure 8). This system has great potential for prefabrication.

Sound transmission is an important non-structural design consideration for multi-family wood frame construction that may control material and construction choices. It was said by Walford (n.d), noise from footsteps impact present a great disturbance effect in multifamily construction, Noise from voices should be controlled by airborne insulation.To achieve satisfactory sound transmission control, sound-absorbing wall boards, acoustic mats, and acoustic sealers filling the gaps between wall and floor elements are often used according with Cheung (2010) . Continuity of materials that form the exterior walls - plasterboard, asphalt plates, wood cement boards, stones of coating, etc - and the use of absorbing materials, such as wool and fiber insulation, are strategies that should be applied for isolating the dwelling from the external noise. The production process of wood in relation to other industrial products requires low energy consumption and respects nature.

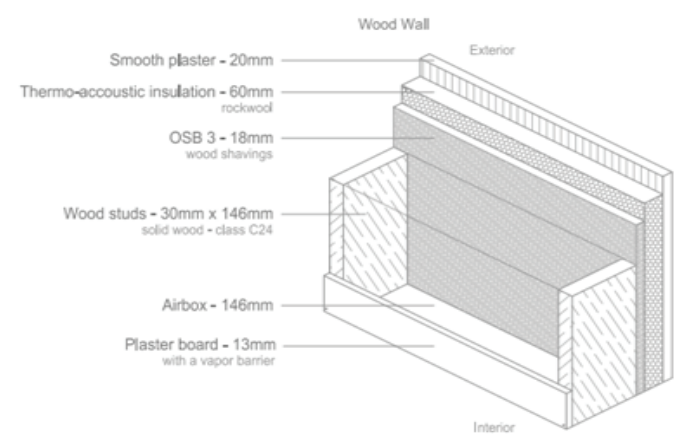

Figure 7 - Constructive details of a wood wall with ETICS system

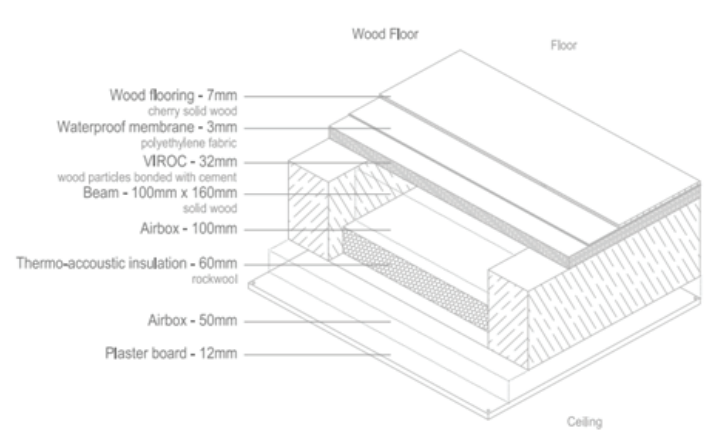

Figure 8 - Constructive details of a wood floor 
In the Table 1 and Table 2 are presented the results of a functional, environmental and economic analysis of a wood wall and a wood floor, respectively.

Table 1. Table showing a functional, environmental and economical analysis of a wood wall

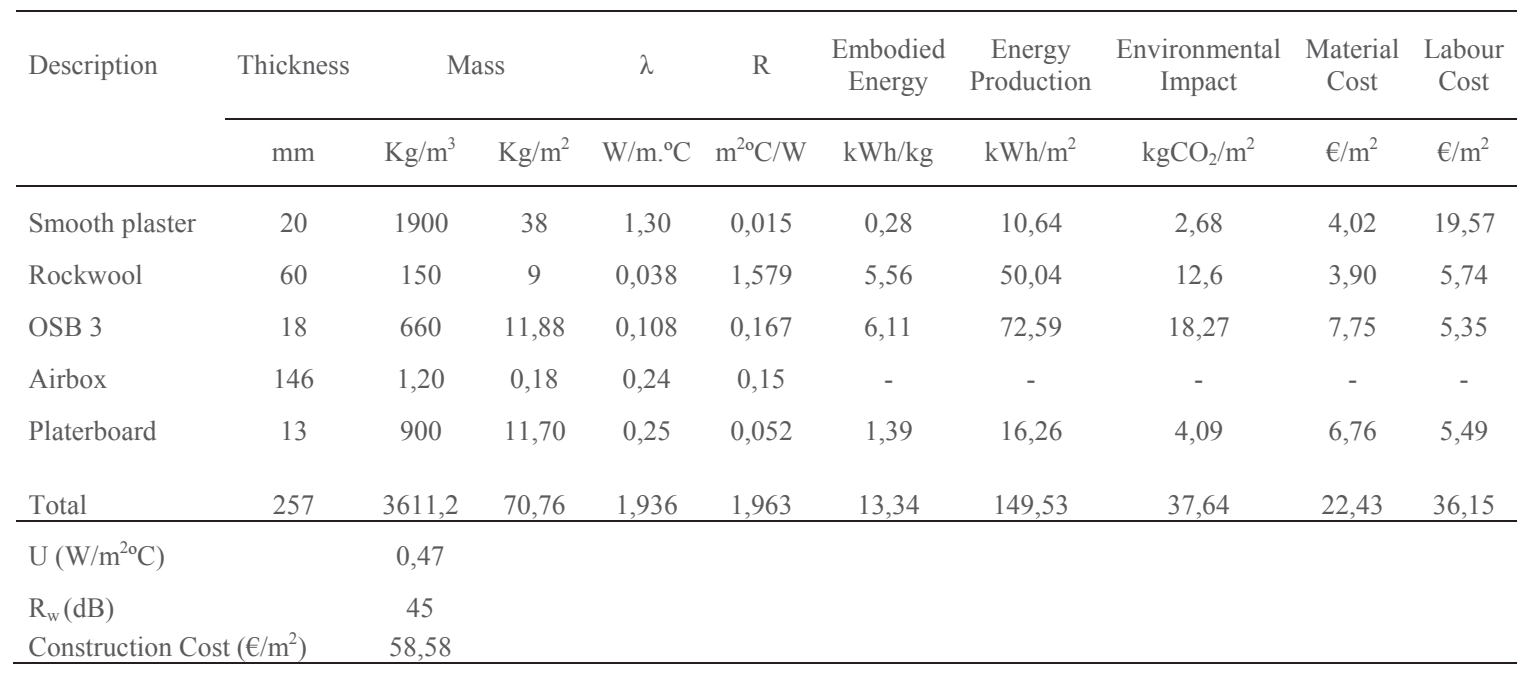

Table 2. Table showing a functional, environmental and economical analysis of a wood floor

\begin{tabular}{|c|c|c|c|c|c|c|c|c|c|c|}
\hline Wood flooring & 7 & 656 & 4,59 & 0,15 & 0,047 & 11,11 & 51,02 & 12,84 & 6,90 & 2,75 \\
\hline VIROC® & 19 & 1200 & 22,8 & 0,23 & 0,083 & 10,56 & 240,77 & 60,6 & 18,75 & 5,08 \\
\hline Airbox & 100 & 1,20 & 0,12 & 0,24 & 0,15 & - & - & - & - & - \\
\hline Rockwool & 80 & 40 & 3,20 & 0,038 & 2,105 & 5,56 & 17,79 & 4,48 & 5,84 & 1,37 \\
\hline VIROC® & 19 & 1200 & 22,8 & 0,23 & 0,083 & 10,56 & 240,77 & 60,6 & 18,75 & 5,08 \\
\hline \multicolumn{2}{|l|}{$\mathrm{R}_{\mathrm{w}}(\mathrm{dB})$} & 51 & & & & & & & & \\
\hline \multicolumn{2}{|c|}{ Construction Cost $\left(€ / \mathrm{m}^{2}\right)$} & 68,04 & & & & & & & & \\
\hline
\end{tabular}

The heat transfer coefficient (U) of the element in question was calculated taking into account the parameters defined in RCCTE. In turn, the sound reduction index $\left(\mathrm{R}_{\mathrm{w}}\right)$, for each component was calculated according to the methodology presented by Mendonça (2005) and Patrício (2010). The mass accounted for determining the thermal inertia of the building is called by useful mass.

The Embodied Energy of the solution was obtained by summing the energies used for the production of each material that compose the solution. These values are determined by multiplying the Embodied Energy (corresponds to the amount of energy required for its production and transportation) of each material by the respective masses. The values of the Embodied Energy for each material were taken from Berge (2009). The Environmental Impact is calculated multiplying the Energy Production by the average $\mathrm{CO}_{2}$ emissions of $0,2517 \mathrm{kgCO}_{2} / \mathrm{kWh}$. 
Table 3. Table representing the reference values

\begin{tabular}{lccccc}
\hline \multirow{2}{*}{ Element } & $\mathrm{U}$ & $\mathrm{R}_{\mathrm{w}}$ & $\begin{array}{c}\text { Energy Pro- } \\
\text { duction }\end{array}$ & $\begin{array}{c}\text { Environmental } \\
\text { Impact }\end{array}$ & $\begin{array}{c}\text { Construction } \\
\text { Cost }\end{array}$ \\
\cline { 2 - 6 } & $\mathrm{W} / \mathrm{m}^{20} \mathrm{C}$ & $\mathrm{dB}$ & $\mathrm{kWh} / \mathrm{m}^{2}$ & $\mathrm{kgCO} / \mathrm{m}^{2}$ & $€ / \mathrm{m}^{2}$ \\
\hline Traditional Wall* & 0,47 & 50 & 228,57 & 57,53 & 69,01 \\
Conventional Floor** & 0,6 & 53 & 388,33 & 97,74 & 71,58 \\
\hline
\end{tabular}

* Single-wall mansory (hollow brick, 220mm), Expanded Polystyrene (50mm), and traditional plaster for the exterior and interior $(20 \mathrm{~mm})$

** Lightened floor of prestressed joists and ceramic blocks $(210 \mathrm{~mm})$, wood flooring, polyethylene fabric $(5 \mathrm{~mm})$, rockwool $(30 \mathrm{~mm})$, and plasterboard $(13 \mathrm{~mm})$

Comparing the values of the presented in the Table 3 with the values presented in the figures above we note that, at the functional level, wood walls are thermally identical to the conventional walls, while wood floors are better than traditional floors. Acoustically, both wood walls and wood floors show better indices of sound reduction than traditional solutions.

It is in environmental parameters that wood solutions exhibit significant advantages. Embodied Energy and subsequent Environmental Impact resulting from the manufacture of wooden walls and floors are substantially lower than those provided by traditional floors. This is because the constructive solutions use mostly wood or wood-based products.

The economic parameters are discussed in the following chapter.

\section{CONCLUSION}

As conclusion of this analysis, it can be mentioned the lack of low cost modular prefabricated buildings within the multifamily housing market in Portugal (with steel or wood structure). It is, therefore, in the single family scope that market has focused appearing in this area some offer at reasonable prices, convincing the people of their gains and at the same time sowing the in a low cost construction is possible to offer the same life quality for the residents as it happens in a conventional construction.

Structural wood apartment buildings are executed mostly by wood or its derivates, which denotes ecological and social concerns. It can be a good marketing tool for a construction company. The method of construction is based on materials and prefabricated components which ensure a better control of quality and a significant reduction of wastes. The construction process requires little labor and reduced activities in the site, since most of the components are prefabricated. For being a lightweight solution it dispenses heavy machinery. The repetitiveness of the construction processes potentiates the effect of learning with positive effects on the final quality of the works.

In Portugal, although it is rare the introduction of wood as integral solution in building construction, this trend could be altered. Factors such as: advantages inherent in the use of wood; the update of specific regulations; the propensity for the creation of new companies in this sector; low cost construction; the availability on the market of various wood products and building systems; and the increasing openness of people to this concept are increasing the interest of the market for wood construction.

The prospects for using wood structure in apartment buildings require that the construction industry, the developers, the architects, and the construction engineers begin considering wood frame as a real alternative when deciding on structural material.

\section{REFERENCES}

Berge, B. (2009). The Ecology of Building Materials, Second Edition. Oxford: Architectural Press 
Blauvelt, A. (2007). Some Assembly Required: Contemporary Prefabricated Buildings. Los Angeles: Moca Pacific Design Center,

Cheung, K. (2010). Multi-storey wood frame construction in North America. World Confederation on timber engineering. $\quad$ Retrieved August 18, 2012, from http://www.ewpa.com/Archive/2010/june/Paper_383.pdf?PHPSESSID=kp6fvne92tisofdus2d0hjnv07

Cruz, H; Morgado, L.; Pedro, J. B.; \& Pontífice, P. (2012). Projeto e construção de casas de madeira em Portugal. Jornadas LNEC. Lisboa: Portugal. Retrieved August,16, 2012, from http://jornadas2012.Inec.pt/site_2_Cidades_e_Desenvolvimento/COMUNICACOES/T3_MORGADO c044.pdf

Espíndola, L. R \& Moraes, P. D. (2010). Coordenação modular em sistemas leves de madeira e sistemas mistos. Brasil: Universidade Federal de Santa Catarina. Departamento de Engenharia civil. Florianópolis. Retrieved August 08, 2012, from http://giem.ufsc.br/upload/20090417152912.pdf

Kaufmann, M., \& Remick, C. (2009). Prefab Gree. Utah: Gibbs Smith.

Mahapatra, Krushna \& Gustavson, Leif (2009). General conditions for construction of mulit-storey wooden buildings in Western Europe. Reports, no.59. Växjö University. Sweden: School of Tecnology and Design. Retrieved August 16, 2012, from http://www.concertosesac.eu/IMG/pdf/WP 16.2_Report_EU_59-2.pdf

Mendonça, P. (2005). Habitar sob uma segunda pele: Estratégias para a redução do impacto ambiental em construções solares passivas em climas temperados. Tese de Doutoramento em Engenharia Civil. Guimarães: Universidade do Minho.

Patrício, J. (2010). Acústica nos Edifícios $6^{a}$ Edição. Lisboa: Verlag Dashofer

Poggi, Pascoal (2011). Logement collectif et tertiaire: Construction en bois et niveau BBC. Qualité construction magazine, Janvier/ Février, $\mathrm{n}^{\circ} 124$.

RCCTE. Regulamento das Características do Comportamento Térmico dos Edifícios. Decreto-Lei $\mathrm{n}^{\circ}$ 80/2006 de 4 de Abril

Staib, G.; Dorrhofer, A.; \& Rosenthal, M. (2008). Components and systems: Modular Construction, Design, Structure, New Technologies. Basel: Birkauser Verlag.

Vessby Johan (2008). Shear walls for multi-storey timber buildings. Thesis for the degree of licentiate of engineering. School of Technology and Design. Sweden: Växjö University. Retrieved August 08, 2012, from http://nu.diva-portal.org/smash/record.jsf?pid=diva2:206355

Walford, G.B. Multi-storey Timber Building in UK and Sweden. (n.d) NZ Timber design journal, issue 2, $\begin{array}{llllll}\text { volume } & 10 . & \text { Retrieved } & \text { August } & \text { 2012, }\end{array}$ http://www.timberdesign.org.nz/timberdesign/fckeditor/UserFiles/File/10-

2/MultiStorey_timber_building_in_UK_and.pdf 